\title{
"Where mediocrity is tolerated"-Rugby Sevens and the management of diversity in South African rugby
}

Bernard Cros

\section{(2) OpenEdition Journals}

Electronic version

URL: https://journals.openedition.org/eastafrica/410

DOI: 10.4000 /eastafrica. 410

ISSN: 2790-1076

Publisher

IFRA - Institut Français de Recherche en Afrique

\section{Printed version}

Date of publication: 1 September 2013

Number of pages: 87-105

ISSN: 2071-7245

\section{Electronic reference}

Bernard Cros, "'Where mediocrity is tolerated"-Rugby Sevens and the management of diversity in South African rugby", Les Cahiers d'Afrique de l'Est / The East African Review [Online], 47 | 2013, Online since 07 May 2019, connection on 09 December 2021. URL: http://journals.openedition.org/ eastafrica/410 ; DOI: https://doi.org/10.4000/eastafrica.410 


\title{
"Where mediocrity is tolerated"- Rugby Sevens and the management of diversity in South African rugby
}

\author{
Bernard Cros
}

\section{Introduction}

With apartheid officially a thing of the past since the mid-1990s, race should no longer be a justification for discrimination in the "New South Africa". Yet the country's rugby union professional elite is still characterized by blatant racial imbalance: there are many more White $-70 \%$ to $80 \%$ depending on the competition - than Black and Coloured players, and all seem to occupy specific positions on the teams according to race1. This process, known as "stacking", or "positional segregation", defines as "players from a certain racial or ethnic group being either over- or under-represented at certain positions in team sports" (Coakley 1988: 257). Explanations revolve around concepts of centrality and periphery of the various positions, i.e. their impact on results and team functioning. Stacking was first studied in the United States in the 1960s in baseball and American football, and has been confirmed to various extents in other sports in a number of countries with troubled racial histories such as Australia, Britain and New Zealand ${ }^{2}$.

Strangely enough, South Africa has been largely ignored. In previous work, we underlined racial inequality and forms of stacking in South African fifteen-a-side rugby union, the most popular form of the sport (Cros 2009). However, its seven-a-side variation, which has grown exponentially around the world since the first Sevens World Cup was organized in 1993, deserves attention

\footnotetext{
1 The racial categories of White, Black, Indian and Coloured are a legacy of apartheid with no scientific basis, but they still inform South African society and mindsets to the core. Phenotypic identifications are still frequent and often entail conclusions about an individual's moral, physical or psychological qualities. Skin colour commands stereotyping, which in turn reinforces people's places in society in an endless vicious circle. The paradox is that, by definition, the concept of race must be used to assess 'transformation'. In the anti-apartheid movement, the term 'Black' described anybody who was not White and was oppressed by the authorities, but I chose to use it to describe effectively Black South Africans so as to maintain a difference with the so-called 'Coloured' population, a diverse mixed-race group specific to South Africa because this terminology makes sense in the local context. In the same anti-apartheid context, it was the term African that was used to denote Black South Africans, but this seems today irrelevant if not absurd in so far as all South African citizens are African, because they were either born or live on the African continent, including Afrikaners, whose name means "African" in Afrikaans.

${ }^{2}$ For a detailed review of the literature on stacking, see for instance Buffington (2005).
} 
too because empirical study indicates that more Blacks have been included in the sevens than in the fifteens national team. This could lead to the hypothesis that sevens is a more racially open and less discriminatory football code. However, it is still not taken as a "serious" sport by many, and this would rather confirm the binary management of diversity in South African rugby based on racial stereotypes prevalent in the Western world about Blacks as natural athletes and Whites as hard-working and intelligent (see Brown et al, 2003). Eventually, as political authorities have been demanding more equal racial participation in national sports teams, the growth of sevens could be seen as a "development tool", an expression connoting affirmative action demands by the New South Africa's political authorities in order to close the gap created by centuries of segregation and injustice between the Whites and the "historically disadvantaged" communities. In sport, it meant increased participation of Blacks, Coloureds and Indians in the national teams, including rugby. Changes in the racial balance of the teams were to serve as a symptom of "transformation".

Therefore, this study intends first to quantify racial participation in the South African rugby sevens team (the Blitzboks) in the International Rugby Board (IRB) competitions compared with the fifteens team (the Springboks) in test rugby, as well as the positional breakdown of the sevens team players, before delving into the factors influencing the results, essentially the cultural and sporting specificities of rugby sevens, and the racial views prevalent in South African rugby union.

\section{1- Methodology and sample}

The statistical material was built up from a systematic compilation of the participation of players in the sevens and fifteens national teams for the period 2000-2011 by looking at the two variables of race and positioning. The South African Rugby Union website database was used to analyse the 148 test matches played by the Springboks and the 100 IRB Sevens World Series tournaments in which the Blitzboks took part. All in all, 137 different players were selected at least once for the sevens team. However, except for Table 1, each player was counted once for every season he played instead of just once to reveal the amount of trust awarded to players by coaches, which adds up to a total of 289 players as a whole (a player selected only once is less relied upon than another selected six or seven times). A total of 1,317 caps (i.e. selection to a tournament) were awarded. Among the Springboks, 159 players were selected for a total of 508 seasons and 3033 caps. Racial affiliation was based on team and player individual photographs available in various books and on different rugby websites, as well as on the author's personal knowledge. Players were arranged into three groups, White, Black and Coloured. 


\section{2- Results}

I expected the sevens team to include only slightly more Blacks and Coloureds than Whites, and many less than in fifteen-man rugby. However, Table 1 shows that the Whites remained the number one group over the period ( $56 \%$ of the total). At fifteens, the gap is much bigger with a breakdown of over $73 \%$ of Whites and under $27 \%$ of non-whites. Interestingly, though they account for only $14 \%$ of the sample, Black Blitzboks obtained more caps than their Coloured and White counterparts (11.9 compared with 9.5 for Coloureds and 9.1 for Whites), whereas each White Springbok obtained over twice as many caps as his Black teammates, but barely 1.7 more caps than the Coloureds. Coloured caps in both teams are close to the overall average.

Table 1 - Racial breakdown of the South African sevens and fifteens teams, 2000-11.

\begin{tabular}{|c|c|c|c|c|c|}
\hline & & Blacks & Coloureds & Whites & Total \\
\hline \multirow{2}{*}{$\begin{array}{c}\text { Players* } n \\
(\%)\end{array}$} & Sevens & $20(14.6)$ & 40 (29.2) & 77 (56.2) & 137 \\
\hline & Fifteens & $17(10.7)$ & 25 (15.7) & $117(73.6)$ & 159 \\
\hline \multirow{2}{*}{$\begin{array}{r}\text { Caps* } n \\
(\%)\end{array}$} & Sevens & $243(18.6)$ & 372 (28.2) & 702 (53.3) & 1,317 \\
\hline & Fifteens & 149 (4.9) & $472(15.6)$ & $2,412(79.5)$ & 3,033 \\
\hline \multirow{2}{*}{$\begin{array}{l}\text { Average } \\
\text { caps per } \\
\text { player }\end{array}$} & Sevens & 12.2 & 9.3 & 9.1 & 9.6 \\
\hline & Fifteens & 8.8 & 18.9 & 20.6 & 19.1 \\
\hline
\end{tabular}

Year-by-year figures tell a marginally different story (Table 2). Non-White participation has actually decreased (from 58\% to 35\% of players and from $49 \%$ to $38 \%$ of caps), over the period, but proportions fluctuated quite a lot. If on average, the Whites were indeed the largest of the three groups, they accounted for over $50 \%$ of the players in only five of the twelve seasons, reaching $65 \%$ twice, while there was an equal number of Whites and non-Whites in 2006. Thus the share of Whites, which increased to two-thirds of the sample in 2003, decreased to one third in 2008, before reaching the two-thirds mark again in 2011. 
Table 2 - South African Sevens team racial mix (289 players), 2000-11, $n$ (\%)

\begin{tabular}{ccccc}
\hline & Whites & Blacks \& Coloureds & Blacks & Coloureds \\
\hline $\mathbf{2 0 0 0}$ & $10(41.7)$ & $14(58.3)$ & $4(16.6)$ & $10(41.7)$ \\
$\mathbf{2 0 0 1}$ & $16(55.2)$ & $13(44.8)$ & $4(13.8)$ & $9(31.0)$ \\
$\mathbf{2 0 0 2}$ & $14(58.4)$ & $10(41.6)$ & $3(12.5)$ & $7(29.2)$ \\
$\mathbf{2 0 0 3}$ & $17(65.4)$ & $9(34.6)$ & $1(3.8)$ & $8(30.8)$ \\
$\mathbf{2 0 0 4}$ & $10(47.7)$ & $11(52.3)$ & $4(19.0)$ & $7(33.3)$ \\
$\mathbf{2 0 0 5}$ & $13(44.8)$ & $16(53.2)$ & $6(20.7)$ & $10(34.5)$ \\
$\mathbf{2 0 0 6}$ & $12(50.0)$ & $12(50.0)$ & $5(20.8)$ & $7(29.2)$ \\
$\mathbf{2 0 0 7}$ & $12(46.2)$ & $14(53.8)$ & $7(26.9)$ & $7(26.9)$ \\
$\mathbf{2 0 0 8}$ & $7(33.3)$ & $14(66.7)$ & $6(28.6)$ & $8(38.1)$ \\
$\mathbf{2 0 0 9}$ & $8(44.5)$ & $10(55.5)$ & $5(27.8)$ & $5(27.8)$ \\
$\mathbf{2 0 1 0}$ & $16(59.3)$ & $11(40.7)$ & $5(18.5)$ & $6(22.2)$ \\
$\mathbf{2 0 1 1}$ & $13(65.0)$ & $7(35.0)$ & $4(20.0)$ & $3(15.0)$ \\
Total & $148(51.2)$ & $141(48.8)$ & $51(18)$ & $90(30.8)$ \\
\hline
\end{tabular}

A comparison of Tables 2 and 3 (number of caps) shows that White players were only marginally more often selected than their number should allow (Whites account for $51.2 \%$ of players and obtained $53.3 \%$ of the caps available) over the period. Such comparison may help to detect patterns of racial bias as in the first three years, when Whites were given a clear-cut advantage (for example, in 2000 , they obtained $50.8 \%$ of the caps though they represented only $41.7 \%$ of the squad). Since then, the difference has remained limited (+/-3 percentage points except in 2007 and 2008) and non-Whites have even enjoyed more caps in six of the last eight years under study. Finally, in all but three years, Coloureds have been markedly more numerous than Blacks. 


\begin{tabular}{ccccc}
\hline & Whites & Black \& Coloureds & Blacks & Coloureds \\
\hline $\mathbf{2 0 0 0}$ & $60(50.8)$ & $58(49.1)$ & $13(11)$ & $45(38.1)$ \\
$\mathbf{2 0 0 1}$ & $83(64.8)$ & $45(35.1)$ & $9(7)$ & $36(28.1)$ \\
$\mathbf{2 0 0 2}$ & $97(64.2)$ & $54(35.8)$ & $9(6)$ & $45(29.8)$ \\
$\mathbf{2 0 0 3}$ & $59(66.3)$ & $30(33.7)$ & $8(9)$ & $22(24.7)$ \\
$\mathbf{2 0 0 4}$ & $44(44.9)$ & $54(55.1)$ & $16(16.3)$ & $38(38.8)$ \\
$\mathbf{2 0 0 5}$ & $50(46.7)$ & $57(53.2)$ & $21(19.6)$ & $36(33.6)$ \\
$\mathbf{2 0 0 6}$ & $53(48.2)$ & $57(51.8)$ & $30(27.3)$ & $27(24.5)$ \\
$\mathbf{2 0 0 7}$ & $38(39.6)$ & $58(60.4)$ & $34(35.4)$ & $24(25)$ \\
$\mathbf{2 0 0 8}$ & $39(40.2)$ & $58(59.8)$ & $31(32)$ & $27(27.8)$ \\
$\mathbf{2 0 0 9}$ & $57(47.5)$ & $63(52.5)$ & $29(24.2)$ & $34(28.3)$ \\
$\mathbf{2 0 1 0}$ & $63(58.3)$ & $45(41.7)$ & $25(23.1)$ & $20(18.5)$ \\
$\mathbf{2 0 1 1}$ & $59(62.1)$ & $36(37.9)$ & $18(18.9)$ & $18(18.9)$ \\
Average & $702(53.3)$ & $615(46.7)$ & $243(17.2)$ & $372(29.5)$ \\
\hline
\end{tabular}

Table 3 - South African Sevens team racial mix (1,317 caps), 2000-11, $n(\%)$

In fifteen-man rugby, players are trained as either backs or forwards, and then further specialize at one of the five positions of each of the two groups (Table 4). The forwards are the biggest, heaviest players on the team, whose function is to secure ball possession before, in theory, handing it over to the faster players, the backs, who run and score tries. Sevens teams not only include more backs than forwards on the pitch (4 and 3 instead of 7 and 8 in fifteens), but sevens being above all a running game, many of those required to play forward are in fact identified as backs in fifteens. Overall $76.6 \%$ of the Blitzboks are considered as backs at fifteens. The largest players of fifteens teams, the props and hookers (first row) and locks (second row), are excluded because they are not adapted to a running game (since 1999, only one has actually donned the Blitzbok jersey). As a few bulky players are nevertheless needed, they are taken from the ranks of the lighter forwards, the flankers and $\mathrm{N}^{\circ} 8$ (third row players), who generally combine above average height and weight ${ }^{3}$ with speed and endurance, and are often considered as the best athletes on a team. However, the forward positions of a fifteens rugby team at which players are supposed to specialize are less relevant at sevens because the free flowing nature of play limits fixed position situations in which such specialization matters. The qualities of strength and power of forwards are thus irrelevant as the struggle for ball possession is limited and not as physical and frequent. The "set pieces", the

${ }^{3}$ The average size of the South African sevens back row players is $1 \mathrm{~m} 87$ and $100 \mathrm{~kg}$. Computed from the players' pen pics available on the SARU website. 
lineouts and scrums, which are fundamental at fifteens, serve merely to put the ball back in play and don't involve a high amount of strength at sevens. Finally, almost one third of all players are originally wings, the fastest players on the pitch, whose running abilities are paramount in sevens.

Table 4 - Positions of the 289 South African Sevens team's players in fifteens rugby, 2000-11

\begin{tabular}{|c|c|c|c|c|}
\hline$n(\%)$ & $\begin{array}{l}\text { Total } \\
(\% \text { on } \\
\text { team) }\end{array}$ & Black & Coloured & White \\
\hline Wings & $\begin{array}{c}90 \\
(31.1)\end{array}$ & $\begin{array}{c}20 \\
(22.2)\end{array}$ & $\begin{array}{c}49 \\
(54.4)\end{array}$ & $\begin{array}{c}21 \\
(23.3)\end{array}$ \\
\hline Fly-half & $\begin{array}{c}14 \\
(4.8)\end{array}$ & $0(0)$ & $\begin{array}{c}10 \\
(71.4)\end{array}$ & 4 (28.6) \\
\hline Fullback & $\begin{array}{c}31 \\
(10.7)\end{array}$ & $\begin{array}{c}11 \\
(35.5)\end{array}$ & 7 (22.6) & $\begin{array}{c}13 \\
(41.9)\end{array}$ \\
\hline Centres & $\begin{array}{c}38 \\
(13.1)\end{array}$ & $6(15.8)$ & $4(10.5)$ & $\begin{array}{c}28 \\
(73.7)\end{array}$ \\
\hline $\begin{array}{c}\text { Scrumhal } \\
\mathbf{f}\end{array}$ & $\begin{array}{c}33 \\
(11.4)\end{array}$ & $0(0)$ & $8(24.2)$ & $\begin{array}{c}25 \\
(75.8)\end{array}$ \\
\hline $\begin{array}{c}\text { Utility } \\
\text { backs* }\end{array}$ & $\begin{array}{c}18 \\
(6.2)\end{array}$ & $0(0)$ & $1(5.6)$ & $\begin{array}{c}17 \\
(94.4)\end{array}$ \\
\hline Backs & $\begin{array}{c}224 \\
(77.5)\end{array}$ & $\begin{array}{c}34 \\
(15.2)\end{array}$ & $\begin{array}{c}82 \\
(36.6)\end{array}$ & $\begin{array}{c}108 \\
(48.2)\end{array}$ \\
\hline Flankers & $\begin{array}{c}50 \\
(17.3)\end{array}$ & $13(26)$ & $8(16)$ & $29(58)$ \\
\hline$N^{\circ} 8$ & $\begin{array}{c}14 \\
(4.8)\end{array}$ & 4 (28.6) & $0(0)$ & $\begin{array}{c}10 \\
(71.4)\end{array}$ \\
\hline Hooker & $\begin{array}{c}1 \\
(0.3)\end{array}$ & $0(0)$ & $0(0)$ & $1(100)$ \\
\hline Props & $0(0)$ & $0(0)$ & $0(0)$ & $0(0)$ \\
\hline Locks & $0(0)$ & $0(0)$ & $0(0)$ & $0(0)$ \\
\hline Forwards & $\begin{array}{c}65 \\
(22.5)\end{array}$ & $\begin{array}{c}17 \\
(26.2)\end{array}$ & $9(12.3)$ & $\begin{array}{c}40 \\
(61.5)\end{array}$ \\
\hline Total & $\begin{array}{c}289 \\
(100)\end{array}$ & $\begin{array}{c}108 \\
(100)\end{array}$ & (100) & (100) \\
\hline
\end{tabular}

Racially, a short majority (51.8\%) of the backs are Black or Coloured and a large majority $(61.5 \%)$ of forwards are White. This pattern is slightly different from what can be observed in the Springboks, which do include more Black and Coloured backs than forwards, but in lower proportions (minus 15\% backs, minus $20 \%$ forwards). Blacks do not come first in any of the positions, but rank second in four categories. They also come second among forwards, clearly ahead of Coloureds, the reverse being true among backs. However, Blacks are entirely excluded from three positions: hooker, fly-half and scrumhalf. The Blitzboks 
described as "utility backs", players who can occupy several backline positions (such as wing and fullback or fly-half and centre), are almost all White. Whites are dominant in seven of the nine categories, including five with over $70 \%$, Coloureds being the favourite choice at the other two (wing and fly-half).

\section{3- Discussion}

The results reveal patterns of inequality - Whites dominate at most positions - and egalitarian tendencies compared with fifteens. Many more Blacks and Coloureds play for the Blitzboks than for the Springboks, and Black and Coloured backs are more numerous at three positions. Why then should sevens be more accessible to non-Whites? Two broad sets of explanations can be mobilized that are both derived from what is understood to be the "real" nature of rugby, and consequently its value in society, or at least in the rugby community:

- The cultural and sporting specificities of each version of the game;

- Racial views and the related conclusions about the inferiority or superiority of the groups they are applied to.

\subsection{Is rugby sevens even rugby? Cultural and sporting specificities}

\subsubsection{Image and environment: sevens as a pastime}

The traditional image of sevens rugby is an end-of-season tournament, a pretext to have a good sweat with friends before gathering round beer and barbecue in the spring or early summer sun with the wives and kids, a final get together before the holiday break. Some sevens tournaments have been traditionally organized to raise money for charities, such as the famous Middlesex Sevens organised at Twickenham, London, since 1926. According to the website of the IRB, the closest thing rugby has to an international federation, "for nearly a century Sevens rugby remained a wonderful pastime, played by clubs and teams to wind up a long and demanding season or as a gentle build-up to the new one"4 (Thau 2011). What is around the pitch is just as important as what is on it. Despite the prestige of such tournaments as the Melrose Sevens, the oldest in the world (founded in 1883), the Richmond Sevens (1936, in London) and the Hong Kong Sevens (1976), sevens is about having a good time - it is the "fast and fun format" (Bortchardt S. 2011). Tournaments involve many games, spread on one or two days; one can walk in and out of the stadium and find a match going on. Advertising for sevens tournaments insist on the nice day out people will have: the holiday atmosphere, food and drinks, and other events, such as concerts and games for children. The slogan for the December 2011 South African leg of the IRB World Series in Port Elizabeth was "rugby's biggest party". "Family fun at

\footnotetext{
${ }^{4}$ Emphasis is mine.
} 
the USA Sevens is both entertaining and affordable" (USA Sevens). The culture, image and environment of sevens are less likely to foster a 'serious' approach to rugby than fifteen-a-side, which involves heavy preparation and concentration, the whole environment and actors gearing up for the big 80-minute match. In South Africa, the fifteens national team's matches are indeed often lived as a national celebration, rugby being, especially for the Afrikaners, "the chosen sport of a chosen people" (Archer and Bouillon 1982). In a nutshell, sevens is a game, fifteens is a sport.

\subsubsection{Character: less power, more speed}

Sevens was created as a variation of fifteens in the Scottish Borders in 1883, and ever since, two major differences have remained: seven players instead of fifteen take the field for two halves of seven minutes instead of forty. With less than half the players on a similar pitch, there is much more space available, so that pace, running and passing have come to embody the game, and have contributed to the conception of sevens as fifteen-a-side's carefree, cheerful, less serious cousin. The famous Scottish BBC commentator Bill McLaren's description of the Hong Kong Sevens tournament encapsulates the nature of sevens. "There is (...) scintillating running and handling, which is what the game is supposed to be all about" (1991: 166). Everything is made to increase the pace of the "high-octane version of rugby union" (Newcombe and Jordan 2010) and offer a show to the viewers, not to mention that it is much easier to follow than fifteens. As Table 5 shows, the athletic character of sevens upholds qualities that reinforce an image of light-heartedness and fun.

Table 5 - Compared features of fifteens and sevens rugby

\begin{tabular}{|c|c|c|}
\hline Features & Fifteens & Sevens \\
\hline Length in minutes & 80 & 14 \\
\hline Struggle for the ball & Frequent and intense & Sparse and superficial \\
\hline Passing frequency & Can be low & High \\
\hline Running & $\begin{array}{l}\text { Irregular, mostly short } \\
\text { distances }\end{array}$ & $\begin{array}{l}\text { Almost permanent, } \\
\text { often long distances }\end{array}$ \\
\hline Pace & Stop and go & Free flowing \\
\hline Kicking & Frequent & Rare \\
\hline $\begin{array}{l}\text { Set pieces (scrums and } \\
\text { lineouts) }\end{array}$ & Frequent & Rare \\
\hline $\begin{array}{l}\text { Average points scored per } \\
\text { minute }\end{array}$ & Low & High \\
\hline $\begin{array}{l}\text { Average metres covered } \\
\text { by player in a match }\end{array}$ & $\begin{array}{l}>5,800-6,953<= \\
35 / 87 \mathrm{~m} \text { per minute } \\
\text { (Cuniffeet al) }\end{array}$ & $\begin{array}{l}3,000=>200 \text { per } \\
\text { minute }\end{array}$ \\
\hline Environment & Serious & Fun \\
\hline
\end{tabular}

The physical qualities required to play sevens are essentially speed and short-term endurance, i.e. a capacity to sprint up and down the field for 14 minutes, three times a day. The heaviest forwards (props and locks) are simply 
not selected because they cannot run fast enough and long enough. Sevens appears physically unidimensional, while technical skills, such as quick ball handling and footwork, are paramount to beat a direct opponent "one-on-one". The nickname of the national team, the Blitzboks (or Blitzbokke in Afrikaans), a portmanteau word amalgamating Springboks and blitr, emphasizes the capacity to strike hard and fast, just as the South African Air Force jet fighter before which the team posed at the onset of the 2009 season. ${ }^{5}$

Sevens seems to be about shunning your opponent, when fifteen-a-side players never shy from physical challenge. It is a collision sport whereas sevens is a dodging sport, at odds with the traditional view of rugby in South Africa, which is above all about hard-fought rucks, ferocious tackles and sheer strength. This was how the Springboks won their best victories and put their stamps on their opponents by crushing them through superior physicality, not slick ball handling. In South African rugby, identified as the utmost symbol of White domination over the country during apartheid - "the opium of the Boer" according to antiapartheid ANC activist and former rugby player Arnold Stofile (Carlin 2008: 65) - the White man's view of the world and practices remain paramount. But for many Blacks and Coloureds, rugby was just "the brutish, alien pastime of a brutish, alien people" (Ibid: 40).

\subsubsection{Not masculine enough?}

Admiration for physical impact leads us to look at the definition of masculinity in South African rugby, which has much to do with how White, especially Afrikaner, communities consider men, insofar as it is their view of the world, of human relations and of a person's worth which informs the rugby world. In South Africa, rugby has been identified as a tough man's game since it started to organise at the end of the nineteenth century. As a reinterpretation of the British Victorian "muscular Christianity", but away from its original patrician roots as a gentleman's sport, rugby was adopted in rural Afrikanercommunities as the measure of a man, and used by Afrikaans-speaking teachers and predikante, Calvinist reverends of the Dutch Reformed Church, as an educational instrument from the beginning of the twentieth century. No young Afrikaner male could escape it; it was part of his 'masculinisation' process, a way to learn about solidarity, physical and moral courage and toughness, and disinterested effort needed to ensure the survival of a tight-knit community. It often came as a complement to work on the farm, where similar qualities are needed and physical effort is rewarded, and fitted in well in their worldview. Rugby developed as a community sport and helped to give structure and substance to Afrikanerdom's masculine ideal, and even became a key component of radical Afrikaner nationalist discourse from the 1930 s onwards. As John Nauright put it: "White

5 2011. Photograph. http://www.rugby15.co.za. Web. 6 Jan 2012. <http://www.rugby15.co.za/wpcontent/uploads/2010/02/Springbok-Sevens-Squad-for-George-and-Dubai-1024x6181.jpg>. 
rugby was violent... tied to imperial culture for English-speaking Whites, national identity for Afrikaners and English-speakers, and cultural superiority and masculinity for all White men" (1997) ${ }^{6}$. It is therefore no surprise that for Afrikaners the essence of a rugby player, and of a man, is best embodied in forwards, the big men who tend to indulge in collision more than in running. Views of the value of forwards and the despicable frailty, utter uselessness and lack of manliness of the backs are commonly held as a joke around the rugby world, as in this quote by former Australian forward and sportswriter Peter Fitz Simons:

Rugby backs can be identified because they generally have clean jerseys and identifiable partings in their hair... come the revolution the backs will be the first to be lined up against the wall and shot for living parasitically off the work of others [the forwards]. ${ }^{7}$

All this may be linked to a conception of virility - or lack thereof. The limited contacts at sevens make a player less of a man. Interestingly, sevens is routinely called "the shortened version" or "the abbreviated game". In some ways, a sevens player is not 'real'; in horse talk, he is not entire anymore. If fifteens players are stallions, sevens are geldings, castrated horses. Gelding is supposed to diminish a horse's aggression. Similarly, by indulging in sevens, a player is emasculated, neutered, "de-masculinised" and becomes thus more feminine. Opinions vented on rugby forums reveal low consideration for sevens, "sort of like women's rugby" (Capostagno 2010). Another comment on the same page read: "Well, [sevens] is entertaining. (...) Many great players played here first and developed skills. But it's not that crash bash intelligent 15-man rugby the BOYS play."

It is worth noting here that in the British imperial ideology "the colonized were gendered female" (Maclean 1999: 3). The association of the racially different with the feminine promotes a derogatory view of Blacks and Coloureds by robbing them of their manhood. Female, not-White and childish, sevens is at the exact opposite of the traditional rugby attributes - masculine, White and adult. The kit used by the South African sevens team for the 2011-12 season did nothing to ease the effeminate identity of sevens. The green and white shorts earned it the nickname "diaper kit", or "undies on the outside". As a blogger put it: "All it needs is a bib and a bonnet to complete the overall look." The kit, which "went viral on social networks", "attracted scorn to rugby men", and a South African designer considered that it made players look "like acrobats, not rugby players" (Skosana 2011). The acrobat simile evokes a frequent derogatory comparison with ballet dancers made by rugby players. In 2009, Springbok coach Peter De Villiers justified the very dangerous eye-gouging of an opponent by one of his players in comparable terms: "Why don't we go to the nearest ballet shop,

${ }^{6}$ This has been also observed in New Zealand, another 'rugby-mad country', where "rugby has been a key element in the construction of a legitimate masculinity" (MacLean 1999: 1) of the colonial man. 7http://www.rugbyforum.co.za/QuotesVolume1.htm. Web. Oct. 28, 2011. 
get some nice tutus, get a great dancing show going, no eye-gouging, no tackling... and all enjoy it" (Sapa-AFP 2009). Rugby's traditional and accepted virility allows players to disregard official rules. It is possible to go beyond the established limits of modern organized sports to maintain the masculine ideal of the rough game of rugby in which a "real rugby man" never complains. Such mechanical association of Coloureds and Blacks with the feminine ignores the fact that Coloured and Black rugby did develop views similar to the Whites. For instance, in Coloured working-class areas of the Cape (District 6 and Bo-Kaap. Nauright 1999: 29), rugby acquired an educational character-building function for young men, based on the exacerbation of "the tough masculinity taught in schools and promoted in the Muslim community" (Nauright 1999: 54) as well as violent and intimidating play on the pitch.

Another aspect of the Afrikaner masculine rugby ideal is the necessity of teamwork, so essential among forwards at fifteens, where much emphasis is laid on collective fight for the ball in the "set pieces" (scrums and line-outs) and rucks. Without his teammates, a forward is nothing. Being a (rugby) man involves sacrificing for the group in a manner that will make you "one of the boys", and this is much less the case at sevens.

\subsection{Racial views}

\subsubsection{Positioning and stacking patterns}

Each position on a rugby team is supposed to command specific physical, technical and psychological qualities. The unequal distribution, deliberate or unconscious, of players by coaches and staffs into the various positions of a team according to race and to the supposed "gifts" racial groups enjoy and the qualities required at the various positions is called stacking. In South African fifteen-man rugby, Whites are systematically trusted at positions where intelligence and vision are essential, such as fly-half and $\mathrm{N}^{\circ} 8$, and at the positions where strength matters (forward, centre). These positions are deemed "central". On the other hand, Blacks and Coloureds are more used in "peripheral" positions, essentially in the backline, where they form the overwhelming majority of wings (or wingers), the most peripheral position relegated to the side of the field, far from where decisions are made. Other positions with higher than average Black and Coloured participation are scrumhalf and fullback. Are these features also common among the sevens team?

Three positions, all in the backline (wing, fly-half and fullback), include more Blacks and Coloureds than Whites and six are predominantly White (centre, scrumhalf, utility back, flanker, $\mathrm{N}^{\circ} 8$ and hooker). A considerable majority $(72.2 \%)$ of the Blitzboks wings are either Coloured or Black, which is higher than with the Springboks, where wing is the only position where Blacks and Coloureds 
have been a majority to start matches since $2000 .{ }^{8}$ The wing position gives the impression that speed is all there is to it, and this is why Blacks and Coloureds are so often chosen to play sevens. All you have to do is run fast which is not something to be worked on, or that comes with experience, you have it or you don't - contrary to strategic vision and muscles, which can be worked on. Running seems to be a natural gift, which Blacks seem to enjoy aplenty. Speed appears as an innate, almost animal, quality; Whites are on the side of humanity, non-Whites on the side of nature. ${ }^{\text {It }}$ so happens that sevens favours the expression of speed and improvisation, which, as these quotes from media and official sources prove, Black people are seen as naturally endowed with, and confirm a pattern of discrimination observed in fifteen-a-side. Since Blacks and Coloureds have to be selected, let them be chosen at wing, a peripheral position in fifteens but a position where their natural qualities can be useful in sevens. Fullbacks are less influential in sevens, but it is a position where speed is also essential, which explains the majority of non-Whites (56.7\%).

Fly-half is a paradoxical case. In South African fifteens, Whites enjoy a virtual monopoly over that position considered as the most central of all, because intelligence and decision-making are paramount. He is the "general of the backline and frequently of the whole team. He is like a point guard in basketball, the midfield general in soccer or the quarterback in American football. He has a pivotal role with the responsibility of deciding whether the backs should run with the ball or whether he should kick to gain the best advantage for his side" (SARU 2009) His cognitive qualities - intelligence, adaptability, composure - are identified with the White race and endow him with superiority. That is enough to exclude non-Whites. Why then should $71.8 \%$ of the Blitzbok fly-halves be Coloureds? A likely hypothesis is that the fly-half is much less influential in sevens; it is the scrumhalf who is the "brains" - the strategist - of a sevens team. Predictably, Whites prevail heavily ( $76 \%$ of the sample) at that position, three of them having even been captain. The issue of cognitive superiority can be observed for another category of players described as "utility backs". Such players, who may occupy several positions in the backline, are almost all Whites (only one was not). This can be linked to their "versatility", a capacity to adapt to different situations, often as replacements for an injured teammate, and a quality in keeping with the perception of superior White intelligence. Whites therefore dominate in the most strategically central position (scrumhalf), in the category where adaptability is a key (utility backs) but also in the positions where power

${ }^{8}$ In reality, since 2000, 15 Blacks and Coloureds played wing for the Springboks, and... 21 Whites, but 11 of them had less than three caps at that position - only 2 lacks and oloureds were in that situation - and 7, not originally wings, including two forwards, simply joined in as replacements after injuries forced coaches to improvise. Only 8 of them were real wing specialists (against 11 Blacks and Coloureds).

${ }^{9}$ As an example, one can quote a 2007 awareness campaign for the protection of cheetahs, organized by a wildlife trust, which set up a race between the most famous Coloured player, wing Bryan Habana, and a cheetah. The cause was noble but the event perpetuated the animal view of the Black man. The "speedy winger" lost (Cleary 2007). 
and weight are important. This is the case of centres (73\% of the sample), the sturdiest of all the backs, with bodies that liken them to flankers (often around $1 \mathrm{~m} 85$ and $100 \mathrm{~kg}$ ), of $\mathrm{N}^{\circ} 8$ and flankers (who are forwards).

Finally, it is worth considering that sevens involves less complicated strategies. "Sevens is spontaneous and liberating particularly now that Fifteens has become so professional and the patterns and tactics are so set... There are ... tactics in sevens but largely you put guys on the field and you let them play" (Josh Lewsey, sevens and fifteens international for England; Newcombe \& Jordan 2010). The notion that spontaneity and a lesser demand for carefully thought-out tactics are needed could be just another justification to trust Blacks and Coloureds more in VII because they are likely to create chaos on the pitch through unpredictable moves and electrifying accelerations, when Whites would be more at ease in the fifteen-man game where they can display their qualities of intelligence and organisation.

\subsubsection{Ideology at work?}

In Marxist terms, the apparently natural repartition of rugby tasks among Whites, Blacks and Coloureds could be likened to the reproduction of a racial division of labour, made according to the qualities associated with each group, and of the ensuing specialisation of tasks meant to maintain domination of the "master group", the Whites. In a seemingly spontaneous way, players seem to be distributed into the various functional tasks on the pitch and into the two codes (sevens being more racially inclusive than fifteens) according to the physical and intellectual abilities.

Sevens also serves as a political security valve to show that Black athletes are valuable assets to a South African national team. The increase of "racial diversity" in national teams is one of the pet subjects of sporting and political authorities, constantly complaining about Black under-representation in sports, although Blacks and Coloureds sometimes account for over half of the age groups squads. By granting them easier access to the sevens team, South African rugby displays its goodwill. Though Andy Marinos, the manager of national teams at SARU, declared that "sevens was not a tool for development" of Black players, it has indeed been used to accommodate Black participation in the White-dominated rugby environment. Marinos recognizes the difficulty for such players to take it to the next stage as few have been given an opportunity by Super rugby ${ }^{10}$ coaches before or after shining with the Blitzboks. At best, sevens is described, as by former Springbok coach Rudolf Straueli, as a "finishing school" (Momberg 2011) for young up-and-coming fifteens players (the average starting age on the sevens team is 22). No less than 32 Blitzboks,a solid $23.3 \%$,

10 Super Rugby is a yearly competition played by 15 professional franchises from South Africa, Australia and New Zealand, and considered as the highest level of rugby just below test matches between nations. 
went on to play test rugby (31 for South Africa, one for Ireland). Exactly half of them (16) were either Black or Coloured, among whom 14 backs and 2 forwards. As only 26 Black and Coloured backs were selected for the Springboks, it means that $53.8 \%$ of them got sevens caps. By comparison, only $18 \%$ of all the Springbok backs played for the sevens team. Sevens is a de facto stage for athletes who would otherwise not get the chance to play against world-class players in front of big crowds in an international environment.

Therefore, it can be argued that sevens is a way for South African rugby to manage diversity by increasing Black participation, albeit in a peripheral manner, i.e. allowing Blacks and Coloureds a larger share of the new racial dispensation while keeping power firmly in White hands, in other words, paying lip service to racial "transformation", South Africa's grand democratic ambition since apartheid, while maintaining the status quo. Racial specialisation is at work here: Blacks and Coloureds are more legitimate playing sevens as their natural qualities prepare them for the accomplishment of the required tasks, placed in the less admired, less central, positions and football code - sevens is a peripheral practice compared to fifteens -, while Whites remain overwhelmingly dominant in fifteen-a-side with a monopoly over the central positions. It is still difficult for South African rugby to go beyond the "fragmented... community identities" (Nauright 1999: 78).

However, the proportion of Whites on the sevens team actually increased between 2009 and 2011. Nine of the twelve Blitzbokke who played in the first IRB Sevens World Series tournament of the 2011-12 season were White (75\%). This could indicate that the sevens national team is becoming important for Whites because it is invested with a certain type of power and prestige. In 2005, after a series of narrow defeats in tournaments and refusals by professional franchises ${ }^{11}$ to allow their players to join the team, the then SARU president Brian van Rooyen recognised that "we have made a mistake by not giving enough attention to Sevens rugby. It will not happen again and this team is now second after the Springboks" (Bortchardt D. 2005). SARU now contracts most players directly with interesting wage plans compared with what some regional unions can afford, and dedicates specific administrative, medical and athletic structures and personnel to the squad. Playing for the sevens team doesn't mark a man as an oddity as much as it used to, it is even possible to live off it. It is also an additional competence to a resume as professional athletes are also workers seeking the best possible training in order to maximise their capacities and get the highest possible returns. However, the most frequent criticism levelled at sevens is that the best players don't take part. Indeed, the pool is often limited to second- or third-rate players pinched from the university teams or provincial sides because playerssee the Currie Cup unions, Super rugby franchises and the Springboks as their priority.

${ }_{11}$ The Super Rugby professional franchises are not ruled by the IRB but by Sanzar, an independent structure set up by the South African, New Zealand and Australian rugby unions. 
The composition of sport teams depends very much on the views and prejudices of management. Since 1999, all the head coaches of the national sevens team have been either Black or Coloured. It might explain why more Blacks and Coloureds have been selected, but as they don't form the majority of players, it is also possible to argue that Black and Coloured coaches either reproduce the dominant views of South African rugby, or simply do with that the players have at their disposal, and end up choosing more Whites based on pure rugby criteria. Thus the coaching staff seems to have been choosing smaller players purposefully. When a supporter asked the Blitzboks coach Paul Treu why he selected "players who are easily dominated by $\mathrm{N}[\mathrm{ew}] \mathrm{Z}$ [ealand] and Fiji (which) just bulldoze us", he gave a strategic justification: "We aim to play a certain [running] style and size is not the most important factor in that. (...) Remember, when we won the Series a few years ago, we also didn't have the biggest players" (2012). Further research is however needed to understand the motivations of coaches and staffs.

\section{Conclusion}

The racial mixes of the South African sevens and fifteens teams have to do with the respective natures, histories and reputations of each of the two codes, combined with the dominant racial conceptions of rugby players. Sevens is systematically considered in relation to fifteens, and this relation is unequal: whether it be the physical qualities required, prestige, popularity, profitability, or symbolism, the fifteen-a-side version will always be seen as superior. It is highly unlikely therefore that the "stepchild" will become "the crown prince" (Borchardt D. 2005): sevens competitions run parallel to fifteens, it is at best a complementary activity, and it is fifteens that generates all of the money through fan following, broadcasting and advertising. For some, sevens is not even "real" rugby. Such inferior status is enough to disqualify it and explain why it can be more easily associated with Blacks and Coloureds - sevens is invested with much less importance, so it is symbolically possible to allow more non-Whites into a rugby national team. Whichever angle is taken to look at the issue, sevens is placed in a position of inferiority vis-à-vis fifteens. Once this is established, it is easy to infer the inferiority of those who practice it, many of whom happen to be Black or Coloured. This is an undisputed ontological link for many people.

The stepchild has the disadvantages of birth, unmanly culture and derogatory image because rugby is very much seen on the terms of the particular world-view of the White power elite. Condescending comments are still frequent. "[Coloured wing Danwel] Demas has proven beyond a doubt that he does not have what it takes to succeed at this [Super Rugby] level. Let him play out his career in the Vodacom Cup [a minor provincial competition] and IRB Sevens World Series where mediocrity is tolerated" (Borchardt S. 2008).

Yet, changes are on the way. Sevens may have been used to promote Black and Coloured players, but the reorganisation inside SARU and the recently 
heightened profile of the code have been attracting Whites, who would otherwise never have considered a career at sevens. According to Paul Treu, "not only do [players] realise that sevens is a possible stepping stone to higher honours, they can see how it is now a full-time profession, a sport in its own right" (Treu 2012). A sevens contract is no longer "a consolation prize" (Borchardt S. 2008) for players who can't get one in fifteens. Paul Delport, a White scrumhalf who captained the South African Under-21 team to the fifteens world champion title in 2005 , says that the financial incentive was sufficient to make him turn down offers by big fifteens outfits and ignore the stigma associated to sevens. ${ }^{12}$

Finally, the IRB "clearly view sevens as an ideal vehicle in spreading the gospel of the game" (Newcombe and Jordan 2010) and its intense lobbying resulted in the inclusion of sevens in the programme of the 2016 and 2020 Olympics, and has endowed sevens with "mainstream legitimacy" (Beckstrom et al 2010: 11). For Treu it is an occasion to expand the sphere of sevens as a true sport on the line of fifteens: "With rugby sevens forming part of the Olympic Games from 2016 we need to build a culture of sevens rugby in South Africa from school level right through to provincial level" (Botha 2010). The Blitzboks will be among the favourites to obtain a medal, and if they do it will be interesting to look at the importance awarded to race in this success.

\section{Bibliography}

Archer R. \& Bouillon A., 1982, Sport et apartheid. Sous le maillot, la race, Paris: Albatros.

Buffington D., 2005, "Contesting Race on Sundays: Making Meaning out of the Rise in the Number of Black Quarterbacks." Sociology of Sport Journal 22,11, pp. 1937. http://uncw.edu/soccrm/documents/ContestingraceonSundays.pdf.

Retrieved on Jan 8, 2012.

Beckstrom J., Snyder J., Kennedy E. \& McCarthy M., 2010, “Rugby 7's vs 15's."Olympic Coach 22, 1, pp. 11-14.

Borchardt, de Jongh. "SA Rugby wakes up to Sevens." Beeld [Johannesburg] 20 mar 2005. <http://www.news24.com/xArchive/Sport/Rugby/SA-Rugbywakes-up-to-Sevens-20050320>.

Borchardt S., "Danwel disaster."www.keo.co.za. Retrieved on 3 March 2008. <http://www.keo.co.za/2008/03/03/danwel-disaster/>

12 "From 1999 until recently, a Bok Sevens player on an A-category contract would earn R30 000 a month, with B and C players getting R20 000 and R10 000 respectively. To put that into context, a junior player at the Bulls [a Super Rugby team] earns R30 000. As a sevens player, you'd ask a bank for a home loan and they'd laugh at you. Now an A-category Bok Sevens player gets R50 000 a month, with B and C category salaries of R40 000 and R30 000 respectively" (Borchardt S. 2011). Such wages have been criticized as unfair for the Super rugby players, who play a longer and season much more physically challenging for the same amount of money. 
Borchardt S., "The Sevens debate."SA Rugby. April 2008.

<http://www.keo.co.za/2008/04/25/the-sevens-debate/>.

Borchardt S., "Whole new ball game."SA Rugby May 2011.

<http://www.keo.co.za/2011/03/08/whole-new-ball-game/>.

Botha P., "A feast of student rugby at NMMU George." http:/ / www.nmmu.ac.za.

NNMU 23 Nov 2010. Web. 1 Mar 2012.

<http:/ / www.nmmu.ac.za/default.asp?id=3919\&did=\&nid=2652\&mod=newsd etail\&gh $=$ News\&np $=1 \& b h c p=1>$.

Brown T., Jackson J., Brown K., Sellers R., Keiper, S. \& Manuel, W. 2003, “There's No Race On The Playing Field": Perceptions of Racial Discrimination Among White and Black Athletes." Journal of Sport and Social Issues.27, 2, pp. $167-$ 183.

Capostagno A., "SA's sevens new plan." www.keo.co.za29 Nov 2010.<http://www.keo.co.za/2010/11/29/sas-new-sevens-plan/>

Carlin J. 2008, Playing the Enemy. Nelson Mandela and the game that made a nation. New York: The Penguin Press.

Cleary M., "Bryan Habana stirred by call of the wild." Daily Telegraph 20 Oct 2007. Web. 7 Oct

2011.<http://www.telegraph.co.uk/sport/rugbyunion/international/england/23 23709/Bryan-Habana-stirred-by-call-of-the-wild.html>.

Coakley J. 1988, Sport in society: Issues and controversies (6th edition). New York: McGraw-Hill.

Colquhoun, A. et al., SA Rugby Annuals, Cape Town: SA Rugby \& MWP Media, 1999 to 2010.

Cros B. 2009, "Le springbok et la mouette : Rugby, race et construction nationale en Afrique du Sud," in L'Afrique du Sud à l'heure de Jacob Zuma. Perrot, C., Prum, M. \& Vircoulon, T. (eds.). Paris: L'Harmattan, pp. 19-42.

Cuniffe B., Proctor W., Baker J.S. \& Davies B., "An evaluation of the physiological demands of elite rugby union using GPS tracking software.”Journal of Strength and Conditioning Research, 23.4 (2009): 1195-1203.

http://www.ausport.gov.au/ais/nutrition/factsheets/sports/rugby_union.

Grundlingh A. 1999, "Playing for Power? Rugby, Afrikaner Nationalism and Masculinity in South Africa, c. 1900-c.1970," in Making the Rugby World. Race, Gender, Commerce. Chandler, T. \& Nauright, J. (eds.). London: Frank Cass, pp. 181-204.

IRB. "Marvellous end to marvellous season." http://www.irbsevens.com. 21 May 2011. Web. Jan 6, 2012.

McLaren B., Talking of Rugby. London: Stanley Paul, 1991.

MacLean M. 1999, "Of Warriors and Blokes: The Problem of Maori Rugby for Pakeha Masculinity in New Zealand," in Making the Rugby World. Race, Gender, Commerce. Chandler, T. \& Nauright, J. (eds.). London: Frank Cass, pp. 1-26. 
Momberg A., "Sevens squad should produce magic". www.iol.co.za 1 November 2002. Web. 8 Oct, 2011. <http://www.iol.co.za/sport/rugby/sevens-squadshould-produce-magic-1.519844>

Nauright J. 1997, Sport, Culture and Identities in South Africa, Leicester: Leicester University Press.

Nauright J. 1999, "Rugby in Coloured Cape Town," in Making the Rugby World. Race, Gender, Commerce. Chandler, T. \& Nauright, J. (eds.). London: Frank Cass, pp. 27-42, 1999.

Neuman G. 2010, “Title hangover for Sevens Boks.” SA Rugby Annual 2011. Cape Town: SARU \& MWP Media, p. 141.

Newcombe J. \& Jordan N. 2010, "Sevens set to reach out across the globe." Rugby Times, 327, Dec 10, p. 1.

Nicholas C.W., "Anthropometric and physiological characteristics of rugby union football players." Sports Medicine 23.6 (June 1997): 375-396.

No author, "Event Week Schedule." No date. USASevens. Web. 10 Feb 2012. $<$ http://www.usasevens.com/las-vegas/entertainment/>.

No author. "South Africa Rugby Sevens Canterbury 2011/2012 Home Kit."'bttp://footballfashion.org. Football Fashion Org 9 Dec 2011. Web. 18 Nov 2011. <http://footballfashion.org/wordpress/2011/12/09/south-africa-rugbysevens-canterbury-20112012-home-kit/>.

Reeves A., "Afrika may well be the kingmaker."Daily Dispatch (East London), 6 Dec 2011. Web. 6 Jan 2012. <http://www.dispatch.co.za/news/article/2459. >.

Reilly T., "The physiology of Rugby Union football." Biology of Sport. 14.2 (1997): 83-10.

Sapa-AFP. “Anyone for ballet?” Mail \& Guardian(Johannesburg) 1 Jul 2009. Web. 6 Jan $2012<$ http://mg.co.za/article/2009-07-01-anyone-for-ballet>.

Sapa-AFP. "Bok Sevens counting on Afrika." http://www.iol.co.za9 Dec 2010. Web. 10 Jan 2012. <http://www.iol.co.za/sport/rugby/springboks/bok-sevenscounting-on-afrika-1.999422?ot=inmsa.ArticlePrintPageLayout.ot $>$.

SA Rugby. "In the Hotseat: Paul Treu from Stellenbosch." SA Rugby, 4 March 2012. Web. 8 Mar 2012. http://www.sarugby.co.za/article_print.aspx?

SARU. "Origins of the game." Sa.rugby.co.za. Web. 18 Nov 2009. $<$ http:/ / www.sarugby.co.za/ content.aspx?contentid=7534\&statsteam=South Africa\&statscatid $=2,9>$.

Skosana I., “'Diaper' kits attracts scorn to rugby men." Age [Melbourne] 16 Nov 2011. <http://www.thenewage.co.za/Detail.aspx?news_id=33914\&cat_id=22> .

Spink A., "Peter de Villiers: Go to the ballet and grab your tutu if rugby is too rough."Mirror. 20 June 2009. <http://www.mirror.co.uk/sport/rugbyunion/peter-de-villiers-go-to-the-ballet-403347>.

Steele C. \& Aronson J. 1995, "Stereotype threat and the intellectual test performance of African-Americans."Journal of Personality and Social Psychology, 69, 5, pp. 797-811. 
Steyn M. \& Smith JR., "Interpretation of Ante-mortem Stature Estimates in South Africans", Forensic Science International, 171.2 (2007): 97-102. <https://repository.up.ac.za/bitstream/handle/2263/4241/Steyn_Interpretation (2007).pdf>.

Thau C., "Sevens rugby celebrates its 125th anniversary", IRB Sevens, 10 April 2008. Web. Sept 15, 2011.

< http:/ / www.irbsevens.com $/$ archive $/$ tcode $=1040 /$ season $=2007 /$ news $/$ newsid $=2023057$,printer.htmx $>$

Treu P., "Against all odds.” IRB Sevens, 27 Aug 2010. Web. 6 Oct 2012. $<$ http: / / www.irbsevens.com $/$ archive $/$ tcode $=1240 /$ season $=2009 /$ news $/$ newsid $=2039904 . h t m l>$ 